УДК $614.1-057.874$

\title{
ПСИХОФІЗІОЛОГІЧНІ НЕБЕЗПЕКИ В ЖИТТІ СУЧАСНОГО ШКОЛЯРА ТА ЇХ ВПЛИВ НА ФУНКЦІОНАЛЬНИЙ СТАН ОРГАНІЗМУ
}

\author{
С. В. Вархоляк, О. М. Креховська-Лепявко \\ Київський міський медичний коледж \\ ДВНЗ «Тернопільський державний медичний університет \\ імені І. Я. Горбачевського МОЗ Украӥни»
}

\begin{abstract}
У статті висвітлено питання основних психомоторних шкідливостей підліткового віку, їх вплив на якісне здоров'я школяра та негативний прояв у щоденному житті юного організму. Результати моделювання статистичних характеристик цих небезпек дають можливість оцінити масштаби недопустимих змін у майбутньому дорослому організмі й скоректувати стратегію спільних зусиль медпрацівників, батьків та педагогів школи.
\end{abstract}

\section{PSYCHOPHYSIOLOGICAL DANGER IN THE LIFE OF MODERN PUPIL AND ITS INFLUENCE ON THE FUNCTIONAL STATE OF THE ORGANISM}

\author{
S. V. Varholyak, O. M. Krekhovska-Lepyavko \\ Kyiv City Medical College \\ I. Horbachevsky Ternopil State Madical University
}

The article highlights the issue of basic psychomotor hazards in adolescence, their impact on the quality and health of schoolchildren and negative expression in the daily life of the young organism. The simulation results of the statistical characteristics of these hazards make it possible to assess the extent unacceptable changes in the future adult organism and adjust the strategy of joint efforts of healthcare workers, parents and school teachers.

Вступ. На сьогодні одним із важливих завдань кожного громадянина України є зміцнення, формування, відновлення здоров'я. Саме від того, якого способу життя дотримується людина, як вона проявляє себе у праці, навчанні, спілкуванні, як організовує своє дозвілля, як харчується, у якому співвідношенні перебуває її фізична і психічна активність, чи гігієнічно обґрунтований режим праці та відпочинку, залежить функціональний стан організму та стан їі здоров'я.

Здоров'я дітей $є$ індикатором усіх соціальних і економічних негараздів у країні, а також інтегральним показником загального благополуччя суспільства. Проте встановлена негативна динаміка формування стану здоров'я дітей. За період з 2010 до 2015 р. рівень захворюваності на хвороби крові, кровотворних органів, сечостатевої системи зріс у 2,1 раза, кровообігу та кістково-м'язової системи - в 1,9 раза. Збільшилась кількість дітей з розладами психіки та поведінки на 16,7 \%. Серед розладів психіки переважають розла-

(c) С. В. Вархоляк, О. М. Креховська-Лепявко, 2017 ди особистості, непсихотичні та невротичні розлади, пов'язані зі стресом [1, 3].

Основна частина. Зниження резистентності дитячого організму, високий рівень захворюваності, а також зростання чисельності хронічних хвороб та психічних розладів пояснюються погіршенням екологічної ситуації, стресорним навантаженням та зниженням активності імунної системи. Існуючий стан організації режиму навчально-виховного процесу в сучасній школі, інтенсифікація навчання, зростаючий обсяг інформації вимагають від школярів все більшого напруження фізіологічних систем організму, що зумовлює велике навантаження на адаптаційні механізми. Значні негативні зрушення у стані здоров'я та фізичному розвитку дітей шкільного віку насамперед пов'язані з постійним зростанням навчального навантаження на фоні значних порушень умов навчання, виховання, харчування та оздоровлення.

Серед учнівської молоді поширюється тютюнокуріння, вживання алкоголю. Серед старшокласників 
(14-17 років) курять до 20 \% учнів. Підлітки роблять це «за звичкою» - 40 \%, за компанію - 33,8 \%. Окрім того, серед молоді поширюється вживання пива. У межах вікової групи 14-17 років пиво вживають один раз на тиждень 15,5 \% учнів.

Куріння та вживання алкоголю на фоні раннього початку статевого життя негативно впливають на репродуктивне здоров'я. Особливості сексуальної поведінки молоді забезпечує поширення інфекцій, що передаються статевим шляхом. Наразі власний досвід статевого життя мали 27 \% учнів 10-11 класів. Серед учнівської молоді (14-17 років) зареєстровані випадки хвороб, що передаються статевим шляхом [3, 5].

Інтенсифікація навчального навантаження призводить до зростання тривалості перебування дітей у школі за рахунок збільшення кількості уроків. Складність і новизна інформації, збільшення їі обсягів, зміни кількості та якості джерел - усе це свідчить про якісну інтенсифікацію навчання. Навіть звичайні програми сьогодні не під силу майже третині школярів.

Виходячи зі збільшення часу перебування у школі та враховуючи час на виконання домашніх завдань можна стверджувати, що загальна тривалість робочого дня школярів сягає 10-12 годин. Це, у свою чергу, зумовлює скорочення тривалості нічного сну (за даними різних авторів, 20-40 \% школярів сплять менше 8 год на добу), зменшується тривалість перебування на свіжому повітрі і прогулянок (у деяких дослідженнях з'ясовано, що цей компонент режиму дня складає не більше 30 хв). У дозвіллі школярів переважають пасивні види відпочинку, пов'язані з великим зоровим навантаженням: перегляд телепрограм, комп'ютерні ігри та відеоігри. Збільшення тривалості навчання призводить до зниження рухової активності, відмови від фізкультурних процедур і загартування, викликаних нестачею часу $[4,5,7]$.

Систематичні заняття фізичною культурою, які відповідають гігієнічним нормам, у поєднанні з фізичною працею сприяють удосконаленню діяльності центральної нервової системи, поліпшенню діяльності травного каналу, активізації діяльності органів виділення, тобто рухова активність перебудовує діяльність організму, органи і системи якого починають працювати більш гармонійно і економно.

До основних причин тютюнокуріння у дитячому віці спеціалісти зараховують цікавість, вплив кіно і телебачення, наявність зайвих кишенькових грошей, пустощі, бажання не відставати від однолітків і страх бути немодним і несучасним.
Підлітки-курці відстають від своїх однолітків, які не курять, у фізичному, психічному і статевому розвитку. Це відбувається внаслідок спазму кровоносних судин, що постачають кров до ендокринних залоз, насамперед, до гіпофізу і статевих залоз. Тому в таких підлітків пізніше з'являються вторинні статеві ознаки, вони нижчі на зріст, гірше навчаються, слабші фізично.

Розплатою за куріння в дівчат $є$ безпліддя або значне порушення в організмі новонароджених, у тому числі й недоумство. У жінок, які курять тривалий час, нерідко бувають викидні, значно частіше зустрічаються токсикози, недоношеність і передчасні пологи.

За даними соціологічних досліджень, у старших класах курять майже 50 \% хлопців і 30 \% дівчат $[1,3,6]$.

Алкоголізм у підлітковому віці призводить до глибокого зниження інтелекту, ослаблення моральних засад. Спостерігаються зміни характеру у вигляді емоційної холодності, цинічності, грубості, а в багатьох випадках агресивності. Як характерну рису, слід відзначити мінливість настрою: скрадливість і улесливість у ситуаціях, що передбачають вживання алкоголю, змінюються на спалахи гніву та агресії, якщо цьому перешкоджають. Підлітки стають неуважними до близьких, до друзів. Що стосується зовнішніх рис поведінки, то для них характерні безцеремонність, розв'язність, хвастощі, а в умовах суворого контролю вони змінюються на пригніченість та безпорадність.

Проведені дослідження за участю підлітків показали, що серед причин, які змушують вперше спробувати наркотик, на першому місці знаходиться зацікавленість (52,4 \%), далі - приклад друзів (16,7 \%), бажання отримати насолоду (14,8 \%), умовляння друзів, родичів, сусідів (8,1\%), зловживання медичними препаратами та бажання подолати біль чи психічну травму (відповідно 2,2 \% й 1,5 \%). у 2009 р. було виявлено ВІЛ-інфекцію у віковій групі 15-24 роки в $12 \%$ обстежених. Кожному другому учню у віці 13-16 років хоча 6 раз пропонували застосувати наркотик, а близько третини скористалися цією пропозицією [1, 2].

В усіх випадках наркоманії відбуваються зміни психічної діяльності, особистість наркомана деформується у соціально-психологічному плані, що проявляється у відхиленнях поведінки: звужується коло інтересів, з'являється скритність, формується егоцентричний світогляд, йде переорієнтація міжособистісних взаємин. Різко змінюється сфера спілкування, яка звужується до групових інтересів наркоманів. Зміна особистості наркомана робить його потенційним 
правопорушником: з метою задоволення своїх потреб у наркотичній речовині наркомани організовують злочинну діяльність з виготовлення та збування наркосировини. Змінюється ставлення наркомана до особистої гігієни, охайності, самозбереження. Окрім наркотичних речовин, серед дітей і підлітків поширене вживання токсичних речовин, що називається токсикоманією і супроводжується формуванням психічної залежності від них, зростанням толерантності, виникненням абстинентного синдрому й різноманітними психічними, соматичними і соціальними порушеннями.

Антиалкогольна пропаганда в школі насамперед тісно пов'язана з правильною позицією медичного колективу - це організаційно-навчаюча позиція, метою якої $є$ сприяння проведенню виховної роботі як у школі, так і в позаурочний час щодо розкриття алкогольних звичок. Доцільно акцентувати увагу не тільки на формуванні в учнів уяви про шкідливість алкоголю, але й на засвоєнні ними практичного досвіду соціально-правильної поведінки. У зв'язку із цим, поряд із включенням тем про шкідливість алкоголю в навчальні плани природничих дисциплін, антиалкогольна пропаганда може бути представлена i в планах масових заходів школи. Серед них можна рекомендувати диспути «Тверезість - норма життя», «Алкоголь - хвороба чи звичка?», лекції-обговорення «Пияцтво - моральна розбещеність» та ін., читацькі конференції тощо.

Удосконалення методів антиалкогольної просвіти не можливе без розумної організації вільного часу й культурного відпочинку учнів як у школі, так і в сім'і. У цьому напрямку школа повинна тісно співпрацювати із сім'єю, а також батьківськими комітетами. Особливу увагу повинні звертати на школярів із неблагополучних сімей, де батьки зловживають алкоголем. Довірливі бесіди з такими дітьми, доручення їм доповіді на антиалкогольну тематику серед однокласників позитивно впливатимуть на формування їх поведінки. як захисні механізми профілактики від алкоголю можна відзначити два: перший - тверде переконання у шкідливості алкоголю, аморальності його вживання, що призводить до деградації; другий - критичне ставлення до алкогольної ейфорії, наявності доказів, що алкоголь - це наркотик, який призводить до порушень психіки та антисоціальної поведінки $[5,6]$.

Велика виховна роль належить спортивним клубам, секціям, де учні проводять свій вільний час.
У виховній роботі з дітьми доцільно акцентувати увагу на естетичному вихованні школярів, прищеплюванні любові до природи, мистецтва, вихованні позитивних моральних якостей тощо. Досвід показує, що виховання здатності людини досягати творчого натхнення у праці, захопленнях, у спілкуванні з людьми та з природою є найважливішим у психопрофілактиці пияцтва. Разом із тим існує думка, що має місце спадкова схильність до алкоголізму, яка залежить від типу вищої нервової діяльності й стосується особливо молодих людей з «важким» характером. Це потребує визначення груп ризику та запровадження психологічної корекції.

Раціональне харчування - складова частина здорового способу життя. Оскільки на сьогодні багато продуктів містять речовини, що викликають алергічні реакції, знижують специфічну і загальну резистентність, мають канцерогенний, тератогенний, мутагенний ефекти, це позначається на здоров'ї кожного споживача.

3 аналізу анкет виявлено, що рівень споживання риби та рибних продуктів низький. Лише $10 \%$ учнів споживають рибу 2-3 рази на тиждень. До $40 \%$ учнів у раціоні мають рибні страви один раз на місяць. Вивчення структури харчування показало, що лише третина школярів споживає м'ясопродукти щодня, а основна частина - 2-4 рази на тиждень. Молоко і молочні продукти щодня споживають лише $15 \%$ школярів, а 60 \% - лише двічі на тиждень.

У раціоні школярів зменшилося споживання продуктів, що багаті на пектин та клітковину. Чільне місце посідає картопля та страви з неї. 60 \% підлітків мають картоплю на столі щодня. В раціоні харчування переважають борошняні та круп'яні вироби. щодня їх споживають до 73,3 \% учнів. До споживання бутербродів, гамбургерів позитивно ставляться 50 \% учнів. 40 \% підлітків віддають перевагу швидкому харчуванню $[4,5]$.

Висновки. Здоров'я дітей - найцінніше надбання цивілізованого суспільства. Воно створює фізичний, духовний, соціальний, інтелектуальний та фізичний базиси країни. Визначення факторів, що мають негативний вплив на процес формування здоров'я учнів підліткового віку дозволяє розробити та впровадити в життя заходи, що впливають на збереження та зміцнення здоров'я. 


\section{СПИСОК ЛІТЕРАТУРИ}

1. Болтівець С. І. Психологічне обґрунтування заходів профілактичної роботи в навчальних закладах з метою профілактики наркоманії, токсикоманії, алкоголізму / С. І. Болтівець // Практична психологія та соціальна робота. - 2004. - № 12. - С. 56-59.

2. Бялый А. П. Профилактика наркомании - вопрос национальной безопасности и обеспечения выживания нации / А. П. Бялый // Сучасні технології збереження і зміцнення здоров'я здорових : матеріали наук.-практич. конф. - К. : ПП «ППНВ», 2005. - С. 119-122.

3. Гармаш Л. С. Психофізіологічні особливості молодших школярів з нервово-психічними відхиленнями / Л. С. Гармаш, Н. І. Коцур // Проблеми загальної та педагогічної психології : збірник наукових праць інституту психології ім. Г. С. Костюка АПН України. - Т. 6. - Вип. 6. С. $73-75$.
4. Гігієнічні проблеми збереження здоров'я дітей вумовах реформування освіти / Н. С. Полька, Н. В. Сисоєнко, Г. М. Єременко [та ін.] // Гігієнічна наука та практика на рубежі століть : матеріали XIV з'їду гігієністів України. Дніпропетровськ : АРТ - ПРЕС, 2004. - Т. 2 - С. 198-200.

5. Гончаренко М. С. Основы валеологического питания / М. С. Гончаренко. - Х. : Харьковский нац. ун-т им. В. Н. Каразина, 2006. - 367 с.

6. Гребняк Н. П. Факторы риска для здоровья детского населения / Н. П. Гребняк. - Донецк, 2003. - С. 122-159.

7. Жуковская И. В. Оценка функциональных резервов школьников как критерий эффективности физического воспитания / И. В. Жуковская, Н. В. Бобок // Медикоекологічні та соціально-гігієнічні проблеми збереження здоров'я дітей в Україні : зб. тез доп. наук.-практ. конф. з міжнародною участю (Київ, 10-11 вер. 2009 р.). - К., 2009. - C. 179-181.

Отримано 02.03.17 